\title{
Fragments of the seagrasses Halodule wrightii and Halophila johnsonii as potential recruits in Indian River Lagoon, Florida
}

\author{
Lauren M. Hall ${ }^{1, *}$, M. Dennis Hanisak ${ }^{2}$, Robert W. Virnstein ${ }^{3}$ \\ ${ }^{1}$ St. Johns River Water Management District, 525 Community College Parkway, Palm Bay, Florida 32909, USA \\ ${ }^{2}$ Harbor Branch Oceanographic Institution, 5600 US 1 North, Fort Pierce, Florida 34946, USA \\ ${ }^{3}$ St. Johns River Water Management District, 4049 Reid Street, Palatka, Florida 32177, USA
}

\begin{abstract}
The role of vegetative seagrass fragments as a dispersal and recruitment mechanism has received little attention. Research on the potential of vegetative fragments as a dispersal mechanism can help us better understand the ability of seagrass beds to recover from disturbance events, to recruit into new areas, and to survive over long periods. The objectives of this study were to (1) determine the viability of vegetative fragments of Halodule wrightii and Halophila johnsonii as a function of time after removal from sediment, (2) determine whether season of collection affects the fragments' recruitment potential, (3) determine if the source of fragments of $H$. johnsonii affects viability, (4) determine how long fragments float, and (5) determine the frequency of fragment settlement and rooting vs. time. Mesocosm experiments with plants collected from Indian River Lagoon, Florida demonstrated that fragments of $H$. wrightii remain viable during spring for up to 4 wk with a marked decline in survival after 2 wk of drifting. Fall plants had a shorter period of viability with only $5 \%$ of fragments remaining viable by Week 2 . Although the source location of the fragments did not influence viability for $H$. johnsonii, day and season were highly significant for viability, with spring plants remaining viable for up to $4 \mathrm{~d}$ and fall plants remaining viable for twice as long. The short viability of $H$. johnsonii illustrates the importance of rapid settlement when uprooted from a source bed, limiting dispersal to short distances. $H$. wrightii appears to maintain its viability for a longer period of time, indicating that this species may be able to utilize fragments as a dispersal mechanism over longer distances. The vegetative fragments of both $H$. wrightii and $H$. johnsonii had the ability to settle and root in mesocosms, demonstrating that fragmentation is a viable mechanism for dispersal and recruitment for these species.
\end{abstract}

KEY WORDS: Seagrass recruitment - Vegetative fragmentation $\cdot$ Halophila johnsonii $\cdot$ Halodule wrightii $\cdot$ Indian River Lagoon

\section{INTRODUCTION}

Seagrasses are ecologically important submersed marine angiosperms possessing roots, rhizomes, leaves, conductive tissue, and flowers. Although most seagrass species flower and produce seeds as a means of dispersal and establishment, seagrass meadows rely largely on extension and branching of rhizomes for maintenance and expansion (Tomlinson 1974). Seven seagrass species exist in Indian River Lagoon (IRL), the highest species richness of any estuary in the western hemisphere (Virnstein 1999). The seagrass habitat within IRL provides food and refuge for a vast array of species including commercially and recreationally valuable fish (Virnstein 1999). In addition, seagrass beds improve water clarity and decrease erosion by stabilizing sediments and improve water quality by removing nutrients (Dawes 1981, Zieman 1982). 
Information on the relative contributions of vegetative vs. sexual propagation in maintaining existing beds and dispersing to colonize new areas is important for management and restoration of seagrass (Orth et al. 1994). Understanding how seagrass populations become established and persist in perturbed marine environments is a necessary step in conserving these populations (Inglis 2000). Vegetative fragmentation is an effective propagation mechanism for macroalgae and corals, although its importance and success vary among species and season (Highsmith 1982, Kilar \& McLachlan 1986, Ceccherelli \& Cinelli 1999, Smith \& Walters 1999, Walters et al. 2002). Determining the recruitment capabilities of seagrass fragments, the focus of this study, will help scientists and managers understand the nature of seagrass patch establishment.

Seagrass has declined ca. $18 \%$ in the Lagoon and up to $70 \%$ in some areas over a $50 \mathrm{yr}$ period (Virnstein 1999). Other seagrass declines have been noted worldwide (Thayer et al. 1975, Kemp et al. 1983, Orth \& Moore 1983, Cambridge \& McComb 1984, Livingston 1987, Giesen et al. 1990, Dennison et al. 1993). Declines occurring worldwide may be attributed to a number of factors including point and non-point source pollution, eutrophication, boat propeller scars, storm events such as hurricanes and bioturbation from rays, horseshoe crabs, and other benthic organisms (Cambridge \& McComb 1984, Buck 1998). The last 3 factors can create vegetative fragments that may have the potential to establish at another location. If a disturbance capable of uprooting or fragmenting a plant occurs, the plant fragment may be washed away and dispersed to another habitat (Johansson \& Nilsson 1993). Once the cause of the seagrass decline has been removed, recolonization is critical for the long-term survival and recovery of seagrass. Research on the potential of vegetative fragments can help scientists and managers better understand the human and natural impacts on seagrass beds and their ability to recover from disturbance events.

The 2 species examined in this study for fragment recruitment were Halodule wrightii Ashers and Halophila johnsonii Eiseman. H. wrightii is the dominant seagrass species in IRL on a lagoon-wide scale (Morris et al. 2000). H. wrightii grows in a wide range of environments in monotypic stands or mixed with other seagrasses and macroalgae. Sexual reproduction in $H$. wrightii has been reported as infrequent or rare (Phillips 1960, McMillan \& Moseley 1967, Eleuterius 1971).

Halophila johnsonii occurs from Sebastian Inlet south to Virginia Key in northern Biscayne Bay, Florida and is reported nowhere else in the world (Buck 1998). However, it has been suggested that $H$. johnsonii may have originated from the genetically similar $H$. ovalis or $H$. minor from the Indo-Pacific and could be the result of an introduction to IRL (Jewett-Smith et al. 1997, Waycott et al. 2002). Only female pistillate flowers have been observed for $H$. johnsonii, suggesting that male staminate flowers are rare or non-existent (Eiseman \& McMillan 1980, Jewett-Smith et al. 1997, Kenworthy 1997). Preliminary mesocosm work at Harbor Branch Oceanographic Institution suggests that $H$. johnsonii is well suited for vegetative propagation when separated from the parent bed (D. Byron \& M. D. Hanisak pers. comm.), making this species a prime candidate for fragment dispersal as a method of colonization.

\section{MATERIALS AND METHODS}

Study area. IRL is located along the east coast of Florida stretching $250 \mathrm{~km}$ from Ponce de Leon Inlet south to Jupiter Inlet. The fragment donor site for Halodule wrightii was located on the western shore of IRL south of Sebastian River (27 $\left.51^{\prime} 12^{\prime \prime}, 80^{\circ} 29^{\prime} 20^{\prime \prime}\right)$ (Fig. 1). Two donor sites were used for collections of Halophila johnsonii: the 'Inlet' site located on the seagrass flats west of Sebastian Inlet $\left(27^{\circ} 51^{\prime} 20^{\prime \prime}\right.$, $80^{\circ} 27^{\prime} 53^{\prime \prime}$ ) and the 'Lagoon' site located on the western shore north of State Road 60, Vero Beach (27 39' $31^{\prime \prime}$, $80^{\circ} 22^{\prime} 36^{\prime \prime}$ ) (Fig. 1). The Lagoon plants were only collected in August. Sites were chosen based on the persistence of seagrass at these locations.

Fragment collections. Plants were uprooted in clumps by shovel and gently shaken free of sediment. Once collected, fragments were stored in a cooler containing water collected on site and immediately transported to outdoor mesocosms at Harbor Branch Oceanographic Institution $\left(27^{\circ} 32^{\prime} 11^{\prime \prime}, 80^{\circ} 20^{\prime} 58^{\prime \prime}\right)$. Mesocosms had a constant supply of IRL water with a flow rate of 4 tank volume turnovers $\mathrm{d}^{-1}$. Plants were separated into 3 shoot fragments containing an apical meristem. Cuts were made using a razor blade in the center of the rhizome internode. Fragments with 3 shoots occurred at the highest frequency, for both species, in field observations of floating material throughout summer sampling in IRL (authors' pers. obs.).

Tests of fragment viability vs. time and season. Experiments were conducted between April and June 2001 and repeated between August and October 2001 to examine the seasonal effects on viability. These months were chosen based on field observations of fragment availability and seasonal differences in productivity of seagrasses (authors' pers. obs.). Spring/ summer represents the peak growing season of both species, whereas the end of summer/fall represents the time where fragments may be most abundant, but the peak growing season is ending. 


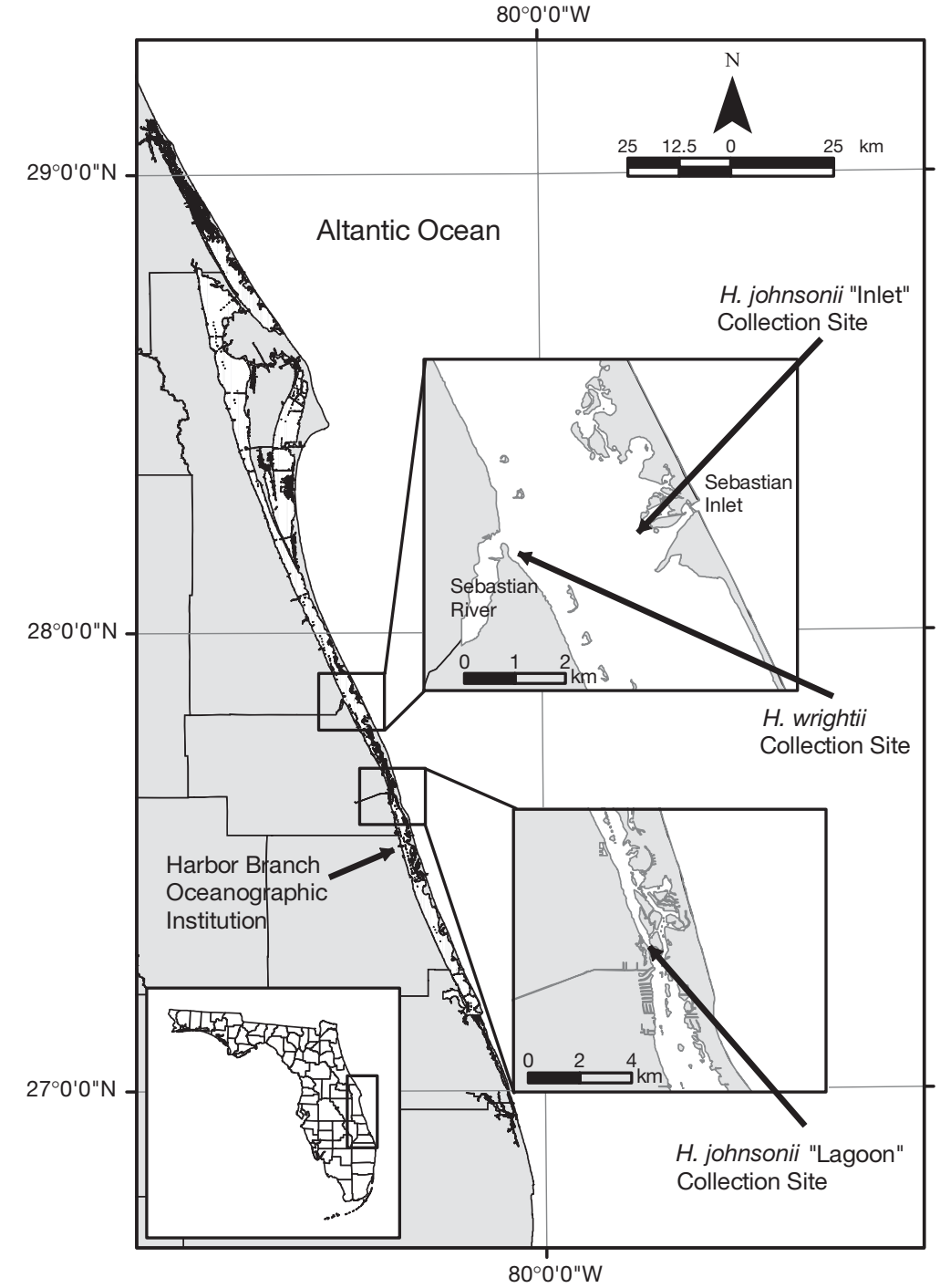

Fig. 1. Location of fragment collection sites in Indian River Lagoon, Florida. The Inlet collection site for Halophila johnsonii was located on the tidal flats west of Sebastian Inlet. The lagoon collection site for $H$. johnsonii was located north of State Road 60 in Vero Beach. The collection site for Halodule wrightii was located south of Sebastian River along the west shore of Indian River Lagoon

as opposed to $8 \mathrm{wk}$ based on the results obtained from the spring experiment.

At the end of each time period, fragments were removed from holding tanks $(\mathrm{n}=20)$. The number of shoots of each removed fragment was recorded, and the fragment was planted in adjacent tubs of sediment within tanks. To minimize the amount of damage to fragments, planting was conducted by carefully holding the fragment rhizome at the sediment surface while pushing into the sediment with fingers, allowing suction to pull the rhizome into the sediment (D. Byron \& M. D. Hanisak pers. comm.).

The apical end of each shoot was marked with a toothpick, and new shoot production was monitored weekly. Planted fragments were monitored for shoot production for at least $6 \mathrm{wk}$. If a fragment produced at least 1 new shoot, it was considered viable.

Tests of fragment viability vs. plant source. To determine the influence of the source of plants, viability between 2 sites was examined. Halophila johnsonii fragments collected from inlet $(\mathrm{n}=$ $100)$ and lagoon $(n=100)$ sites were placed in holding tanks void of sediment for (1) $0 \mathrm{~d}$ (control), (2) $1 \mathrm{~d}$, (3) $2 \mathrm{~d}$, (4) $4 \mathrm{~d}$, and (5) $8 \mathrm{~d}$. Fragments ( $\mathrm{n}=20$ for each treatment) were removed from holding tanks at the end of each time period and carefully planted in viability tubs using the previously described method. Shoot production was monitored weekly. Production of at least 1 new shoot was considered viable.

Additional plants $(\mathrm{n}=48)$ were collected and measured to help explain

Drifting (holding) tanks were equipped with outflow pipes designed to avoid fragment loss. Viability tubs were filled with sediment consisting of 1:1 lagoon sediment and dune sand mixture. Sediment was sifted (mesh size $0.2 \mathrm{~cm}^{2}$ openings) to remove any debris, large fauna, and vegetation. Fragments $(n=100)$ were placed in 5 holding tanks void of sediment to prevent rooting for 5 time periods for each species:

Halophila johnsonii holding time: (1) $0 \mathrm{~d}$ (control), (2) $1 \mathrm{~d}$, (3) $2 \mathrm{~d}$, (4) $4 \mathrm{~d}$, and (5) $8 \mathrm{~d}$ in spring and fall.

Halodule wrightii holding time: (1) $0 \mathrm{wk}$ (control), (2) $1 \mathrm{wk}$, (3) $2 \mathrm{wk}$, (4) $4 \mathrm{wk}$, and (5) $8 \mathrm{wk}$ in spring, $5 \mathrm{wk}$ in fall. The fall experiment was ended at $5 \mathrm{wk}$ any potential differences found in the viability between inlet and lagoon sites. Measurements were made on blade length, blade width, internode length, and rhizome diameter. Measurements were made with a caliper to the nearest millimeter.

Tests of fragment settlement and fragment rooting. This experiment examined the variability of fragment floating and the frequency of fragment rooting over time. Fragments $(n=100)$ were monitored in large tanks ( $\mathrm{n}=5$ tanks per species) containing $15 \mathrm{~cm}$ of sediment weekly for $5 \mathrm{wk}$ for Halodule wrightii and $2 \mathrm{wk}$ for Halophila johnsonii to determine how settlement and rooting are influenced by time to test the feasibil- 
ity of fragments rooting on their own. The number of fragments floating, neutrally buoyant, unattached at sediment level, and rooted was recorded at the same time of day each week. Experiments were conducted between August and October 2001.

Statisical analysis. SAS Statistical Software 8.2 (SAS 1988) was used to analyze data. Data were tested using the Shapiro-Wilk test for normality and an $F_{\max }$ test for homogeneity of variance. Due to the non-normality of the data, an F-approximation to Friedman's test was done using Proc Rank and GLM to see if viability was influenced by the treatment (season and time for first experiment, source and time for second experiment, number of rooted fragments for third experiment). Significant time effects were further analyzed via a Tukey's Studentized Range Test to determine which weeks or days differed from each other (Sokal \& Rohlf 1995). A $t$-test was performed on plant measurement data to determine if there were any differences between inlet and lagoon plant characteristics to help explain any potential differences in the viability between these.

Physical parameters and mesocosm maintenance. During all experiments, mesocosms were monitored weekly for temperature and salinity using a Hydrolab Scout II by placing the sonde in the middle of the water column. Algal growth was cleaned weekly from tub and tank sides to prevent shading. Epiphytes were carefully removed by gently sliding thumb and forefinger up the seagrass blade.

\section{RESULTS}

\section{Tests of fragment viability vs. time and season}

The length of time fragments remained viable varied between species and season. Halodule wrightii fragments remained viable during spring for up to $4 \mathrm{wk}$ (Fig. 2). Fragment viability for $H$. wrightii during fall decreased rapidly, and no fragments remained viable past 2 wk. Both season $(p<0.0001)$ and week $(p=$ 0.0002 ) were significant; however, there was also a significant interaction ( $\mathrm{p}=0.0353)$.

Halophila johnsonii fragments remained viable during spring months for up to $4 \mathrm{~d}$, while fragments collected during fall months remained viable substantially longer, with $55 \%$ of the fragments still viable at Day 8 (Fig. 3). The 2-way ANOVA indicated a significant interaction between season and time with fragment viability. Both season $(p<0.0001)$ and floating time $(\mathrm{p}<0.0001)$ significantly affected viability. Post hoc results presented were performed for season of collection separately due to the significant interaction $(\mathrm{p}<0.0001)$.

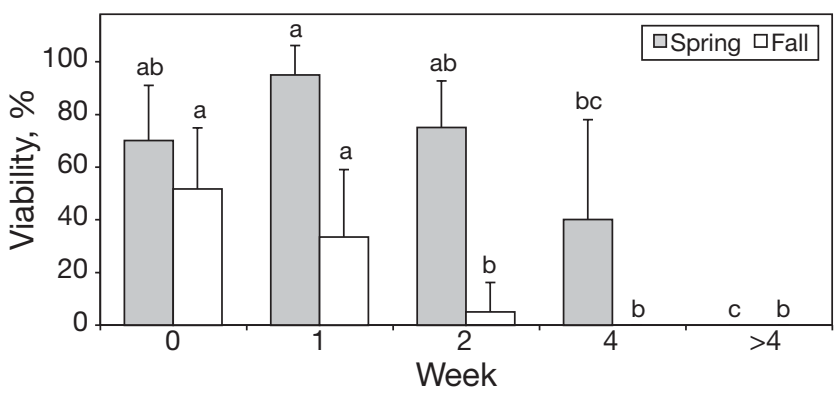

Fig. 2. Halodule wrightii. Viability of fragments of $H$. wrightii (+SE) vs. time during spring (March through May) and fall (September through November 2001) sampling periods. Spring plants were monitored through Week 8 for viability; fall plants were monitored through week 5 for viability. Season was significantly different $(p<0.0001)$. Weeks within each season with

common letters were not significantly different $(p>0.05)$

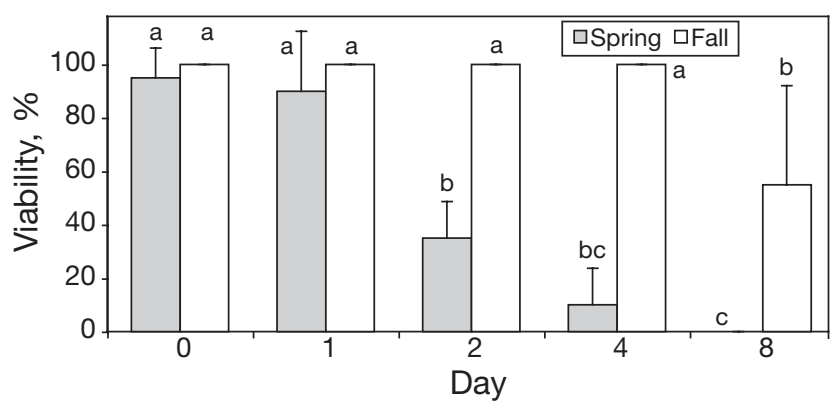

Fig. 3. Halophila johnsonii. Viability of fragments of $H$. johnsonii (+SE) vs. time during spring (April through May) and fall (August through September 2001) sampling periods. Season was significantly different $(p<0.0001)$. Days within each season with common letters were not significantly different $(p>0.05)$

\section{Tests of fragment viability vs. plant source}

The source of Halophila johnsonii did not influence fragment viability ( $\mathrm{p}=0.9108)$; however, there were significant differences in viability over time $(p=0.001)$ (Fig. 4). Fragments remained viable for $8 \mathrm{~d}$ with a significant decrease after Day 4 . There were slight differences among plant measurements between sites, with blade length being significantly greater for Lagoon plants $(t=16.16$; $\mathrm{p}=0.0001)$. There were no differences between source locations for internode length, blade width, and rhizome width.

\section{Tests of fragment settlement and fragment rooting}

The number of settled fragments of Halodule wrightii increased over time (Fig. 5). Within 1 wk an average of 12 fragments had settled to sediment level, and by Week 2 several fragments were rooted. The number of newly rooted fragments, however, was not significantly different over time $(p=0.087)$. 


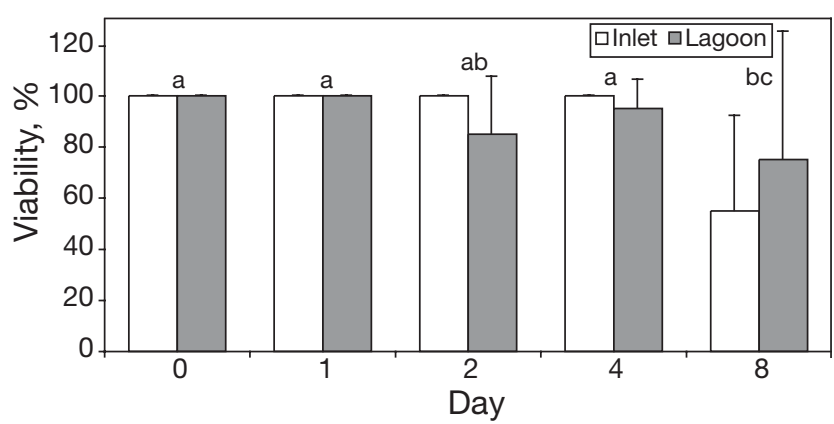

Fig. 4. Halophila johnsonii. Viability of fragments of $H$. johnsonii (+SE) for Inlet and Lagoon plants during fall sampling, August through September 2001. Site was not significant $(\mathrm{p}=$ 0.9108). Days with common letters were not significantly different regardless of source $(p>0.05)$

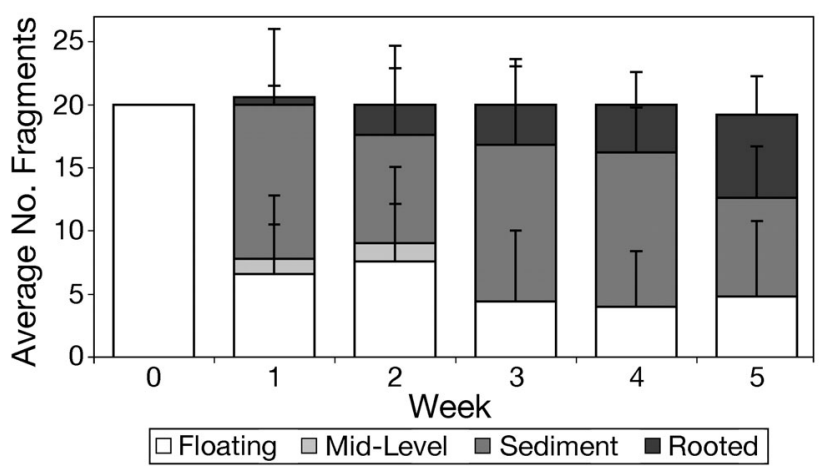

Fig. 5. Halodule wrightii. Location of fragments of $H$. wrightii in water column $(+\mathrm{SE})$ during fall $(\mathrm{n}=100)$. Frequency of rooting by fragments was not significantly affected by week $(p=0.087)$

The average of cumulative rooted fragments reached 6.6 by Week 5, ranging from 3 to 11 among experimental tanks.

Halophila johnsonii showed a trend similar to that of Halodule wrightii, where the number of settled fragments increased over time (Fig. 6). The number of newly rooted fragments of $H$. johnsonii significantly increased over time $(\mathrm{p}<0.001)$, with an average of new recruits reaching 5.6 by Week 2 .

Physical parameters. Temperature ranged from 19 to $34^{\circ} \mathrm{C}$ throughout the study with a mean of $27^{\circ} \mathrm{C}$. Salinity had a mean of 29 and a range from 17 to 35. Salinity was higher in spring and early summer and decreased in late summer and fall in conjunction with a seasonal increase in rainfall.

\section{DISCUSSION}

The ability of vegetative fragments of Halodule wrightii and Halophila johnsonii to successfully settle and reroot has potentially profound implications for seagrass recovery and survival. Settlement of uprooted

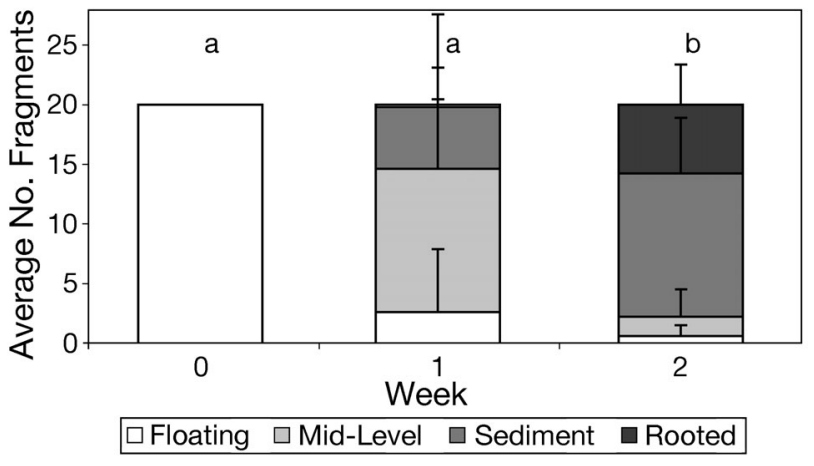

Fig. 6. Halophila johnsonii. Location of fragments of $H$. johnsonii in water column $(+\mathrm{SE})$ during fall $(\mathrm{n}=100)$. Frequency of rooting by fragments was significantly affected by week $(\mathrm{p}<$ 0.0001). Weeks with common letters were not significantly different $(p>0.05)$

vegetative fragments may be a viable recruitment mechanism occurring for these species in IRL, particularly where sexual reproduction is not occurring or is rare. Species possessing seed banks are capable of rapid recruitment into a disturbed area under the right conditions; however, species lacking a seed bank may need to rely on vegetative fragmentation as a dispersal mechanism (Campbell 2003). Although McMillan (1981, 1988a,b) has reported seed reserves for $H$. wrightii and $2 H$. johnsonii congeners in Texas and Panama, no such reserves have been reported in IRL for either species.

Olesen et al. (2004) state that species with fast clonal growth and limited sexual reproduction can effectively grow from gap margins but that this mechanism is not effective when gaps are distant from an existing meadow (e.g. gap scales greater than annual rhizome extension rates). Our research suggests otherwise, where fragments of the fast growing species Halodule wrightii and Halophila johnsonii have the ability to remain viable for periods of time that allow for dispersal at large distances (kilometers). Morris \& Virnstein (2004) observed a rapid recovery of $H$. wrightii in the northern IRL in quiescent, shallow water. This recovery occurred after complete demise of the existing seagrass bed. The initial recovery occurred as small patches, which may be indicative of recruitment by $H$. wrightii fragments.

\section{Seasonal difference}

There are strong seasonal differences in recruitment potential. Campbell (2003) found that the greatest recruitment of Posidonia australis fragments occurred in late spring and early summer followed by late autumn. The optimal reestablishment period for Zostera marina is during late spring and summer 
in Canada, times of high growth and reproduction in this plant; however, this reestablishment period does not necessarily coincide with high fragment availability (Ewanchuk \& Williams 1996) or with maximum growth periods occurring in spring and fall in Chesapeake Bay (Dennison 1987). In our experiments, Halodule wrightii was more successful at recruitment via fragments in spring than fall, while Halophila johnsonii fragments remained viable for a significantly longer period in fall than in spring. The marked difference in viability between seasons may be related to the natural cycles and peak growing seasons for $H$. wrightii and $H$. johnsonii. $H$. wrightii grows fastest throughout the spring and summer months and enters a period of dormancy during the late fall and winter months. $H$. wrightii had distinct increases in percent cover during summer sampling throughout IRL, whereas $H$. johnsonii did not (Morris et al. 2001). Salinity for the $H$. wrightii portion of the study remained above 24, a level where vigorous growth has been reported for this species (McMahan 1968). Temperatures during this portion of the study ranged from 22.3 to $32.1^{\circ} \mathrm{C}$, temperatures measured frequently throughout IRL grassbeds during summer months.

Fragments of Halophila johnsonii remained viable during the spring for up to $4 \mathrm{~d}$. By Day 4, rhizomes began to turn brown and blades were shed readily upon handling. Fragments remained viable substantially longer for $H$. johnsonii collected during fall (August), with $55 \%$ of the fragments still viable at Day 8. Although a decrease in salinity was observed during this experiment, it did not appear to have an effect on the viability of $H$. johnsonii fragments. Dawes et al. (1989) concluded that $H$. johnsonii had a broad tolerance of temperature and salinity and had positive responses from 15 to 35 and between 10 and $30^{\circ} \mathrm{C}$ but did not test for effects at higher temperatures. The temperatures in this portion of the study reached $33.6^{\circ} \mathrm{C}$ and salinity ranged from 17.2 to 32.4 .

Although below-ground measurements for Halophila johnsonii were not obtained, it is possible that rhizomes of summer plants are more substantial than winter plants, allowing for more energy storage and thus may be in a more favorable condition in fall for surviving uprooting from their source beds. This theory could potentially explain the longer survival of drifting fall fragments as opposed to the spring fragments. The ability of $H$. johnsonii to remain viable for longer periods during fall may aid in recruitment to new areas since this season may have a higher abundance of drifting fragments as a result of storm events typically seen in the fall. If this experiment was repeated, initial blade and rhizome measurements may provide insight into this theory.

\section{Implications to new bed formation- distance traveled}

The distances over which fragments of Halodule wrightii and Halophila johnsonii can travel from their source locations is partly dependent upon the length of time they remain viable once uprooted from their source bed. Spring fragments of $H$. wrightii have the potential to travel much greater distances in $4 \mathrm{wk}$ vs. fall fragments, which lose viability by Week 2 . Likewise, fragments of $H$. johnsonii remain viable for an even shorter time than $H$. wrightii (days compared to weeks), thus limiting dispersal to shorter distances from the source bed. In addition to viability, the distances the fragments can travel also depend upon factors such as wind and tidal currents. Harwell (2000) found that fragmented reproductive shoots of Zostera marina had the ability to disperse up to $34 \mathrm{~km}$ from their source bed in Chesapeake Bay. Holmquist (1994) reported drift algae clumps traveling up to $0.5 \mathrm{~km} \mathrm{~d}^{-1}$ in Florida Bay. There can be very large differences in the distances depending upon hydrodynamic conditions in different water bodies.

At current velocities recorded ca. $25 \mathrm{~km}$ from Ft. Pierce Inlet (Smith 1983), fragments could potentially travel $9 \mathrm{~km} \mathrm{~d}^{-1}$. However, tidal currents, as opposed to wind-driven currents, do not continue in the same direction for longer than several hours. For Halodule wrightii fragments, which remain viable for up to 4 wk, new patches could be established substantial distances from a source location. Even Halophila johnsonii fragments has the potential to travel such distances over its $8 \mathrm{~d}$ period of viability. Of course, the shape of IRL likely limits dispersal to far less than this potential distance due to its narrow width in many locations.

\section{Source of fragments}

Halophila johnsonii is found in a wide range of environments in monotypic stands or in beds mixed with macroalgae and other seagrasses (Kenworthy 1993, Gallegos \& Kenworthy 1996, Virnstein et al. 1997). It can be found growing in a variety of locations including sandy subtidal sediments, soft mud in deep water near the mouths of freshwater drainage canals, and intertidal zones (Virnstein et al. 1997). These various locations often produce different phenotypes, with shallow inlet populations possessing shorter blades with a light pigmentation and deeper, interior lagoon populations with less light penetration, possessing longer blades with darker pigmentation. The results of this study indicate that these differences in morphology do not affect the survival and viability of $H$. johnsonii when uprooted from sediment. 
Although source location did not impact the viability of the fragments, source location can be a significant factor when considering the creation of fragments. Extensive populations of Halophila johnsonii occur at or near highly dynamic environments such as the flats inside Sebastian Inlet. The high current velocities are capable of uprooting fragments (authors' pers. obs.), although the specific current velocity capable of doing so for Halodule wrightii and $H$. johnsonii is unknown. Zostera marina can tolerate current velocities of 120 to $150 \mathrm{~cm} \mathrm{~s}^{-1}$ (Fonseca et al. 1983, Fonseca \& Kenworthy 1987), which are higher than velocities reported near inlets in IRL (Smith 1983). Uprooting of seagrass by tidal currents are less likely at a more interior Lagoon location, and plants have to rely on bioturbation or storm events for the creation of these fragments. Therefore, the importance of the source of the bed cannot be illustrated by examining only viability.

Although little is known about the current velocities capable of uprooting fragments, it is well known that the behavior of several large animals often produce seagrass fragments. Seagrass bed disruptions by horseshoe crab Limulus polyphemus, cownose ray Rhinoptera bonasus, and southern stingray Dasyatis sabina have been reported (Orth 1975, Gilbert \& Clark 1981). Packard (1984) observed a foraging behavior where manatees used their forelimbs to uproot seagrass leaving scattered roots and blades behind. The researchers above reported these observations as a negative impact on seagrass beds; however, if the fragments created by these animals are capable of settling and rooting elsewhere, the result may be new patch formation.

Strong tidal currents have the ability to move sediments to a depth of over $15 \mathrm{~cm}$, which can easily bury or uproot existing beds (authors' pers. obs.). Buck (1998) noted that during hurricanes, movement of sediment can easily dislodge seagrass communities, particularly shallowly rooted species such as Halophila johnsonii. Seed-producing species, such as H. decipiens, would have a better chance at reestablishment after such an event than a species with no sexual reproduction. The occurrence of $H$. johnsonii near navigational channels also increases the possibility of prop blowouts, boat propeller scars, and boat groundings, all of which have the potential to produce vegetative fragments.

\section{Tests of fragment settlement and fragment rooting}

The length of time fragments remain viable has no consequences for recruitment unless fragments are able to settle back to the sediment level and root. Halo- dule wrightii fragments showed a settlement trend with all fragments floating at the beginning of the experiment and quickly settling to sediment level within $1 \mathrm{wk}$. By Week 2, several fragments were rooted. This rooting continued through Week 5 when the experiment was ended due to a decline in fragment viability. By this time, the remaining floating fragments were brittle with brown rhizomes and few blades. The remaining blades were losing their pigment and were almost transparent.

The number of newly rooted fragments was greater with greater amounts of algae present in the tanks. Tanks with an overgrowth of Enteromorpha appeared to maintain the fragments at sediment level for a longer period of time, giving them a better opportunity to extend roots. Thus, filamentous or branching algae may serve to help initial attachment.

The number of floating fragments of Halophila johnsonii decreased over time, and the average number of rooted fragments increased. Within their period of viability, fragments, whether floating, at sediment level, or rooted, were all actively producing new shoots throughout the experiment and appeared to remain healthy with white rhizomes and intact pigmented blades. Although $H$. johnsonii remained viable in the fragment viability portion of this study for only $8 d$, rooting in large tanks containing sediment continued throughout Week 2.

The mechanism by which seagrass fragments settle back to sediment level is unknown. Observations indicate that time of day may be a factor, with the majority of the fragments found at sediment level in early morning. By midmorning to afternoon, fragments that had not rooted or were unaffected by algae growth were found floating. Perhaps respiration allowed the fragments to become negatively buoyant at night. Once photosynthesis began and the oxygen in the blades' lacunae accumulated, fragments again became positively buoyant, allowing them to float freely.

To determine whether or not this type of recruitment actually occurs in IRL, observations in the field were made throughout the span of the experiment. Drifting fragments of both Halophila johnsonii and Halodule wrightii were observed at all times throughout the year. The sizes of the fragments ranged from only 1 or 2 shoots to 10 or 11 shoots on some of the largest fragments. Observations of these fragments illustrate that potential recruits are available in the field and that there is a wide range of fragment sizes.

In addition to the availability of fragments, observations were made in the field on the occurrence of new patches, particularly Halophila johnsonii near the Sebastian Inlet collection site. The flats inside of Sebastian Inlet have been monitored frequently since transplant studies were performed in 1998 (Heidel- 
baugh et al. 2000). New H. johnsonii patches have been observed within the vicinity of the transplant sites since that time. New patches of $H$. johnsonii were found on January 30, 2001, adjacent to the transplant plots that had been void of seagrass since October 1998. Although sexual reproduction cannot be completely ruled out, it is unlikely in light of what is known about $H$. johnsonii's reproductive capabilities.

\section{Recommended future studies}

Future studies examining vegetative seagrass fragments and their ability to establish within their period of viability should incorporate a field component, with frequent monitoring to rule out new patch formation by seedlings and/or vegetative growth from adjacent beds. It will then be possible to conclude whether the ability of fragments of Halodule wrightii and Halophila johnsonii to settle and root is not limited to mesocosm tanks and can, in fact, occur in a natural setting.

There is currently no estimate of the abundance of fragments occurring in IRL. It would be useful to develop a method to measure this abundance to give a better understanding of the availability of fragments of Halodule wrightii and Halophila johnsonii. Future work should also examine both the mechanism for fragment creation (current, bioturbation) and the mechanisms for fragment settlement.

\section{CONCLUSION}

Vegetative fragments of both species had the ability to settle and root within the period of viability observed in the mesocosms. This combination of fragmentation, drifting, settling, and rooting is thus a potential recruitment mechanism occurring for Halodule wrightii and Halophila johnsonii in IRL. This ability is particularly important for these 2 species due to the apparent lack or rarity of sexual reproduction in IRL. Although other species of seagrass were not studied in these experiments, fragments of Halophila engelmannii, $H$. decipiens, Syringodium filiforme, and Ruppia maritima have been observed drifting throughout Indian River Lagoon and may also use vegetative fragmentation as a recruitment mechanism.

Acknowledgements. This study was completed in partial fulfillment of a Master's thesis at the Florida Institute of Technology. Special thanks are extended to Dr. G. Wells, Dr. E. A. Irlandi, E. Hall, W. Tweedale, C. Akers, L. Morris, and 6 anonymous reviewers. This work could not have been completed without the support of Harbor Branch Oceanographic Institution (Contribution No. 1593) and St. Johns River Water Management District.

\section{LITERATURE CITED}

Buck E (1998) An endangered species act issue for southeastern Florida: Johnson's seagrass. Congressional Research Service Reports 98-975 ENR, Washington, DC

Cambridge ML, McComb AJ (1984) The loss of seagrasses in Cockburn Sound, Western Australia. I. The time course and magnitude of seagrass decline in relation to industrial development. Aquat Bot 20:229-243

Campbell ML (2003) Recruitment and colonisation of vegetative fragments of Posidonia australis and Posidonia coriacea. Aquat Bot 76:175-184

Ceccherelli G, Cinelli F (1999) The role of vegetative fragmentation in dispersal of the invasive alga Caulerpa taxifolia in the Mediterranean. Mar Ecol Prog Ser 182:299-303

Dawes CJ (1981) Marine botany. Wiley, New York

Dawson CJ, Lobban CS, Tomasko DA (1989) A comparison of the physiological ecology of the seagrasses Halophila decipiens Ostenfeld and $H$. johnsonii Eiseman from Florida. Aquat Bot 33:149-154

Dennison WC (1987) Effects of light on seagrass photosynthesis, growth and depth distribution. Aquat Bot 27:15-26

Dennison WC, Orth RJ, Moore KA, Stevenson JC, Carter V, Kollar S, Bergstrom PW, Batiuk RA (1993) Assessing water quality with submersed aquatic vegetation. BioScience 43: 86-94

Eiseman NJ, McMillan C (1980) A new species of seagrass, Halophila johnsonii, from the Atlantic coast of Florida. Aquat Bot 9:15-19

Eleuterius LN (1971) Submerged plant distribution in Mississippi Sound and adjacent waters. J Mississippi Acad Sci 17:9-14

Ewanchuk PJ, Williams SL (1996) Survival and re-establishment of vegetative fragments of eelgrass (Zostera marina). Can J Bot 74:1584-1590

Fonseca MS, Kenworthy WJ (1987) Effects of current on photosynthesis and distribution of seagrasses. Aquat Bot 27:59-78

Fonseca MS, Zieman JC, Thayer GW, Fisher JS (1983) The role of current velocity in structuring eelgrass (Zostera marina L.) meadows. Estuar Coast Shelf Sci 17:367-380

Gallegos CL, Kenworthy WJ (1996) Seagrass depth limits in the Indian River Lagoon (Florida, USA): application of an optical water quality model. Estuar Coast Shelf Sci 42: $267-288$

Giesen WBJT, van Katwijk MM, den Hartog C (1990) Eelgrass condition and turbidity in the Dutch Wadden Sea. Aquat Bot 37:71-85

Gilbert S, Clark KB (1981) Seasonal variation in standing crop of the seagrass Syringodium filiforme and associated macrophytes in northern Indian River Lagoon, Florida. Estuaries 4:223-225

Harwell MC (2000) Ecological dispersal mechanisms, reproductive ecology and the importance of scale in Zostera marina in Chesapeake Bay. PhD dissertation, College of William and Mary, Williamsburg, VA

Heidelbaugh WS, Hall LM, Kenworthy WJ, Whitfield P, Virnstein RW, Morris LJ, Hanisak MD (2000) Reciprocal transplanting of the threatened seagrass Halophila johnsonii (Johnson's seagrass) in the Indian River Lagoon, Florida. In: Bortone SA (ed) Seagrasses: monitoring, ecology, physiology, and management. CRC Press, Boca Raton, FL, p 197-210

Highsmith RC (1982) Reproduction by fragmentation in corals. Mar Ecol Prog Ser 7:207-226

Holmquist JG (1994) Benthic macroalgae as a dispersal mechanism for fauna: influence of a marine tumbleweed. J Exp Mar Biol Ecol 180:235-251 
Inglis GJ (2000) Variation in the recruitment behaviour of seagrass seeds: implications for population dynamics and resource management. Pacific Conserv Biol 5:251-259

Jewett-Smith J, McMillan C, Kenworthy WJ, Bird K (1997) Flowering and genetic banding patterns of Halophila johnsonii and conspecifics. Aquat Bot 59:323-331

Johansson ME, Nilsson C (1993) Hydrochory, population dynamics, and distribution of the clonal aquatic plant Ranunculus lingua. J Ecol 81:81-91

Kemp WM, Twilley RR, Stevenson JC, Boynton WR, Means JC (1983) The decline of submerged vascular plants in upper Chesapeake Bay: summary of results concerning possible causes. Mar Tech Soc J 17:78-89

Kenworthy WJ (1993) The distribution, abundance and ecology of Halophila johnsonii Eiseman in the lower Indian River Lagoon, FL. Final Report to the Office of Protected Resources, NMFS, NOAA. Silver Spring, MD

Kenworthy WJ (1997) An updated biological status review and summary of the proceedings of a workshop to review the biological status of the seagrass, Halophila johnsonii Eiseman. Office of Protected Resources, NMFS, NOAA, Silver Spring, MD

Kilar JA, McLachlan J (1986) Ecological studies of the alga Acanthophora spicifera (Vahl) Borg. (Ceramiales: Rhodophyta): vegetative fragmentation. J Exp Mar Biol Ecol 104: $1-21$

Livingston RJ (1987) Historic trends of human impacts on seagrass meadows in Florida. Fla Mar Res Pub 42:139-151

McMahan CA (1968) Biomass and salinity tolerance of shoal grass and manatee grass in Lower Laguna Madre. Tex J Wildlife Manage 32:501-506

McMillan C (1981) Seed reserves and seed germination for two seagrasses, Halodule wrightii and Syringodium filiforme, from the western Atlantic. Aquat Bot 11: 279-296

McMillan C (1988a) The seed reserve of Halophila engelmannii (Hydrocharitaceae) in Redfish Bay, Texas. Aquat Bot 30:253-259

McMillan C (1988b) The seed reserve of Halophila decipiens Ostenfeld (Hydrocharitaceae) in Panama. Aquat Bot 31: 177-182

McMillan C, Moseley FN (1967) Salinity tolerances of five marine spermatophytes of Redfish Bay, Texas. Ecology 48: 503-506

Morris LJ, Virnstein RW (2004) The demise and recovery of seagrass in the northern Indian River Lagoon, Florida. Estuaries 27:915-922

Morris LJ, Virnstein RW, Miller JD, Hall LM (2000) Monitoring seagrass changes in Indian River Lagoon, Florida using fixed transects. In: Bortone SA (ed) Seagrasses: monitoring, ecology, physiology, and management. CRC Press, Boca Raton, FL, p 167-176

Morris LJ, Hall LM, Virnstein RW (2001) Field guide for fixed seagrass transect monitoring in the Indian River Lagoon.

Editorial responsibility: Kenneth L. Heck (Contributing Editor), Dauphin Island, Alabama, USA
St. Johns River Water Management District report, Palatka, FL

Olesen B, Marba N, Duarte C, Savela RS, Fortes MD (2004) Recolonization dynamics in a mixed seagrass meadow: The role of clonal versus sexual processes. Estuaries 27: $770-780$

Orth RJ (1975) Destruction of eelgrass, Zostera marina, by the cownose ray, Rhinoptera bonasus, in the Chesapeake Bay. Chesapeake Sci 16:205-208

Orth RJ, Moore KA (1983) Seed germination and seedling growth of Zostera marina L. (eelgrass) in the Chesapeake Bay. Aquat Bot 15:117-131

Orth RJ, Luckenback M, Moore KA (1994) Seed dispersal in a marine macrophyte: implications for colonization and restoration. Ecology 75:1927-1939

Packard JA (1984) Impact of mantees Trichechus manatus on seagrass communities in eastern Florida. Acta Zool Fennica 172:21-22

Phillips RC (1960) Observations on the ecology and distribution of the Florida seagrasses. Professional Paper Series No. 2. Florida State Board of Conservation Marine Laboratory, St. Petersburg, FL

SAS Institute Inc (1988) SAS/STAT-User's Guide. Release 6.03 edn. SAS Institute, Cary, NC

Smith CM, Walters LJ (1999) Fragmentation as a strategy for Caulerpa species: fates of fragments and implications for management of an invasive weed. Mar Ecol 20:307-319

Smith NP (1983) Tidal and low-frequency net displacement in a coastal lagoon. Estuaries 6:180-189

Sokal RR, Rohlf FJ (1995) Biometry, 3rd edn. Freeman, New York

Thayer GW, Wolfe DA, Williams RB (1975) The impact of man on seagrass systems. Am Sci 63:288-296

Tomlinson PB (1974) Vegetative morphology and meristem dependence - the foundation of productivity in seagrasses. Aquaculture 4:107-130

Virnstein RW (1999) Seagrass meadows: fish and wildlife factories. Fla Nat 72(2):18-19

Virnstein RW, Morris LJ, Miller JD, Miller-Myers R (1997) Distribution and abundance of Halophila johnsonii in the Indian River Lagoon. St. Johns River Water Management District, Tech Mem No. 24, Palatka, FL

Walters LJ, Smith CM, Coyer JA, Hunter CL, Beach KS, Vroom PS (2002) Asexual propagation in the coral reef macroalga Halimeda (Chlorophyta, Bryopsidales): production, dispersal and attachment of small fragments. J Exp Mar Biol Ecol 278:47-65

Waycott M, Freshwater DW, York RA, Calladine A, Kenworthy J (2002) Evolutionary trends in the seagrass genus Halophila (Thouars): insights from molecular phylogeny. Bull Mar Sci 71:1299-1308

Zieman JC (1982) The ecology of seagrasses of South Florida: a community profile. FWS/OBS-82/25. US Fish and Wildlife Service, Washington, DC

Submitted: December 14, 2004; Accepted: July 29, 2005

Proofs received from author(s): February 20, 2006 